Wolford, W. et al. (2013). Governing global land deals: The role of the state in the rush for

\title{
Governing global land deals: The role of the state in the rush for land
}

\author{
Wendy Wolford, Saturnino M. Borras Jr., Ruth Hall, Ian Scoones and Ben White
}

\begin{abstract}
Over the past decade, there has been a dramatic increase in large-scale land deals, often from public lands to the hands of foreign or domestic investors. Popularly referred to as a 'global land grab', new land acquisitions are drawing upon, restructuring and challenging the nature of both governance and government. In the Introduction to this special issue, we argue for an analysis of land deals that draws upon the insights of political ecology, cultural politics and agrarian studies to illuminate the microprocesses of transaction and expropriation as well as the broader structural forces at play. We argue that 'the state' is often invoked as a key player in land grabbing but states never operate with one voice; rather we need to unbundle the state, to see government and governance as processes, people and relationships. To develop this approach, we focus on territory, sovereignty, authority and subjects not as static objects but as relationships produced in and through place, property, power and production. Understanding the dynamic nature of these relationships is critical to understanding the highly variable form and content of large-scale land deals in different settings around the world. The papers in this special issue help to develop this perspective and this Introduction highlights important areas of convergence among them.
\end{abstract}

\section{Introduction}

Over the past decade, there has been a dramatic increase in large-scale land acquisitions for the purposes of securing access to the means of producing natural resource commodities (see Borras et al., 2011; Deininger et al., 2011; de Schutter, 2011). In just one year, from March 2008 to April 2009, an estimated 40 million hectares of land changed hands; the latest figures from the World Bank suggest that this was twenty times higher than the average annual level of land transfers for the preceding forty years (Arezki et al., 2011: 1). ${ }^{1}$ The motives and the means differ, but transnational and domestic interests have acquired increasing quantities of land throughout the global South for a wide range of purposes, including logging, food, fuel and increasingly bio-fuel production, tropical forest products and plantation forestry, ranching, production of illegal narcotics, access to water or hydropower, precious minerals and metals, oil, natural gas, carbon sinks and protection of flora and fauna and global biodiversity (Zoomers, 2010). While many

\footnotetext{
${ }^{1}$ Original estimates from the World Bank suggested that there was only a tenfold increase in land acquisitions (Deininger et al., 2011: vi) while estimates produced by the International Land Coalition (ILC) and Oxfam are significantly higher. The ILC has documented transfers of 80 million hectares from 2008 to 2011, while Oxfam suggests that more than 227 million hectares have been allocated in large-scale land deals since 2001, with the vast majority of those transfers occurring after 2008. See the ILC/CIRAD forthcoming synthesis report on the Commercial Pressures on Land Research Project cited in Oxfam (2011).
} 
of the land deals conducted in recent years remain speculative - according to Deininger et al. (2011), 78 per cent of the land acquisitions included in their report were not under production - there is widespread concern that the deals will privilege production for external markets while allowing or even facilitating the neglect of local communities, that they will lack transparency or community dialogue and that they will result in displacement of residents with informal or traditional land rights (The Economist, 2011).

While the nature of this so-called 'land rush' is debated (see the forum in the Journal of Peasant Studies, March 2011 for different perspectives on the subject), and the definition and historical novelty of a global land grab increasingly questioned, there is little doubt that something important is happening. Much has been written about land acquisitions in the past five years (Borras et al., 2011; Fairhead et al., 2012; White et al., 2012), but we still need a better framework for an understanding of how land deals are shaping - and being shaped by - the modern nation state. The international community became aware of land grabs in March 2009, several years after what could be described as the beginning of large-scale land acquisitions. We suggest that what sparked international attention was not necessarily the land deals themselves but the spectacular fall of the Ravalomanana government when it attempted to lease almost one third of the country's arable land to a South Korean firm (see Burnod et al., 2013: 357-380). Land has been grabbed before, especially in Africa, and even the size of the Madagascar land deal might not have provoked particular concern (the rest of the world has historically turned a blind eye to land grabbing in Africa), but when a state falls, it is an international matter.

Thus it is probably not a surprise that as international actors turned to land deals, they focused on the state. The global political community suggested that the blame for large-scale deals lay with post-independence states themselves; it was argued that land grabs were happening in states where $f$ the land sector and tenure security are weak' (Arezki et al., 2011: 3; also see Bomuhangi et al., 2011; Deininger et al., 2011). States like Madagascar, Sudan, Ethiopia, Cambodia and Vietnam were depicted as unable to provide the kind of tenure security or formal land markets or even social safety nets that would generate order and protect the national territory. These were the states described as fragile, disorganized or ungovernable because the rule of law appeared not to cover the full extent of their territories. The analyses suggest that improved governance is the key to addressing the most problematic aspects of land transfers, such as forced dispossession, speculative behaviour, corruption and a general lack of transparency (see $\mathrm{Li}, 2011$ for a critique of these assumptions). Multilateral organizations have thus focused on improving the legal and bureaucratic mechanisms with which land deals are conducted and overseen: establishing better contracts, free, prior and informed consent and clear land rights. All of these elements build on earlier agendas; securing transparent and effective land rights, in particular, has been seen as crucial to releasing the entrepreneurial spirit of the rural and urban poor in developing countries (Dwyer, 2013: 309-334; Grandia, 2013: 233-260; see also HLPE, 2011; Landesa, 2011). ${ }^{2}$

\footnotetext{
${ }^{2}$ For at least twenty years, the international community has promoted land rights as a solution for lawlessness, political instability, environmental degradation, production inefficiencies and even political corruption (Morris et al., 2009). The emphasis on land titles and the flexibility of land markets has arguably paved the way for land deals, providing a veneer of legitimacy through formalization (Fairbairn, 2013: 335-356). At the same time, the push for titling forms part of the radical strategy to protest land deals because social movement and civil society activists also argue that communities are being pushed aside precisely because
} 
While good governance and land rights are worthy goals, they are not implemented in a vacuum. In order for our analyses of, and prescriptions for, land deals to be accurate we need to know more about the nature of states themselves; we need to know more about the motivations of particular actors as well as the capacity of governments and the political cultures that shape the path from policy to practice. As some of the authors in this special issue argue, an analysis of governance must include a focus on formal legal mechanisms such as rights, but also on the formal and informal 'bundle of powers' exercised by different actors (Ribot and Peluso, 2003; Peluso and Lund, 2011; also see Burnod et al., 2013: 357-380; Fairbairn, 2013: 335-356). A nuanced analysis of how different actors at various levels within the state think and work, as well as how different kinds of state subjects are created (Baka, 2013: 409-428; Sullivan, 2013: 451-471) is necessary to shift the discussion of land deals from the current Manichean portrayal in which land deals are seen as either providing much-needed capital and technology for third world agricultural production, food security and employment (Ariyo and Mortimore, 2011; Cotula et al., 2009; Deininger et al., 2011; FAO, 2009; Robertson and Pinstrup-Anderson, 2010), or as neo-colonial scrambles for land and resources conducted by predatory investors at the expense of marginal populations abroad (Oxfam, 2010; Via Campesina, 2011).

In this special issue, therefore, we attempt to go beyond the rhetoric of 'land grabs' and weak, fragile or corrupt states. The papers as a whole develop a number of arguments about global land grabs and the state. First, in relation to the concept of land grabs, the papers suggest that our focus should not just be on land or on specific acts of grabbing; rather we need to analyse a host of processes from narratives of legitimation (Baka; Grandia; Oliveira) to subject making (Baka; Sullivan), technology transfer (Buckley) and industrial development policy (Levien) to understand the means by which large-scale dispossession, appropriation and extraction come to be seen as not just possible but even necessary.

In relation to the role of the nation state in land deals, the papers make four key arguments. First, they suggest that states are not simply passive victims in these deals; they are not coerced into accessing foreign capital by selling off pieces of their national territory to more powerful economic or political players. Instead, many states are active, calculating partners in land deals, negotiating the costs and benefits of the contemporary moment in order to maximize returns on what are considered marginal lands or marginal communities. The example of Brazil is a good one. The paper in this issue by Gustavo Oliveira suggests that the Brazilian government has weighed the costs and benefits of various land uses, such as selling land to foreigners or preserving biodiversity for domestic and international environmental concerns. To address multiple interests both within the country and without, the government has established environmental protections in the Amazonian region that then allow it to justify accepting capital investments - foreign and domestic - in the Cerrado region of the central highlands. The Cerrado region has become a territorial reserve for foreign investment into largescale, input-intensive agriculture even as the Amazon remains relatively protected. The

they have customary or traditional forms of access that are not respected in the rush to parcel off areas (Daniel and Mittal, 2010; Landesa, 2011; Oxfam, 2010). 
paper by Michael Levien in this issue provides another example, this time from India. He argues that dispossession has been a 'constitutive feature of the socio-spatial transformations engendered by colonial, post-colonial and neoliberal political economies', but he goes on to show how dispossession has changed over time and place: in the state of Rajasthan, the government works to legitimize its own role as land broker and in so doing sometimes supports land deals and sometimes fosters resistance against them.

Second, states do not divide neatly into those acquiring land and those being acquired; they are not nearly so coherent and unified. Actors within countries are exploiting unevenness wherever they can and often acting against each other in an attempt to mediate access to land. In this issue, Madeleine Fairbairn argues that inequality within Mozambique is at least as important as inequality between countries for determining the outcome of large-scale land deals there. Her paper stresses the role of domestic elites and shows how they draw on different kinds of authority to provide assistance or obstacles to would-be buyers. In one example, one group of local elites held up a land deal initiated by another group of elites because the first group demanded a bribe; in this case, corruption actually shut down a foreign land deal rather than facilitating it. In Madagascar, state representatives generally welcome agribusiness investments, but they compete over the corresponding benefits and, more significantly, over land management authority (see Burnod et al., 2013: 357-380). As Burnod and her co-authors illustrate, Malagasy elites, government officials and local leaders may use land deals as a way to negotiate local land management authority, in some cases exacerbating intracommunity conflicts. These authors argue further that opposition to the Daewoo Logistics land deal of 2009 was more likely a case of internal politicking intended to destabilize the president at the time than a definitive opposition by elites to international land deals.

A third argument developed by the contributions to this issue is that governments around the world have had very different responses to land deals. Brazil, for instance, has reinstated more strict regulations on foreign land ownership (Oliveria), whereas other governments, such as Mozambique, have embraced large-scale land deals with foreign buyers (Fairbairn). And some countries have resisted formal land title in favour of community ownership until pushed by the international community, particularly development banks, to legislate clear property lines. In the paper by Liza Grandia on Guatemala, these property lines preceded large infrastructure projects that then threatened smallholders who were forced to sell to developers.

Fourth and finally, the research in this issue highlights the articulation of different kinds of power within the state; government leaders call on the military, the police and the courts as well as shadowy elements such as paramilitary forces or narcotics traffickers to carry out the implementation and regulation of land deals. The paper by Jacobo Grajales illustrates the multi-faceted expression of state force in Colombia where the president, on one hand, enacted the Victims' Law to grant compensation to victims of the long-lasting armed conflict, yet simultaneously encouraged the rapid development and expansion of oil palm plantations, most of which are supported by the same narcotics traffickers and paramilitary groups who perpetuated the violence on smallholding 
peasants in the first place. Grajales argues that we need to see this sort of violence - the violence that accompanies land takings - as not abnormal or outside the modern state, but as constitutive of it. In making these four arguments, the authors focus on several key components of governance more broadly understood: territory, or the legal extension of state power on the ground; sovereignty, or the capacity of rulers to control the conditions of their own reproduction; authority, or the role of diverse actors in governing at multiple scales, whether legitimate representatives of the state, third party actors such as non-governmental organizations, community leaders or corporate representatives; and subjects and subjectivities, or the constitution and influence of new actors who because of changing property relationships are either empowered or dispossessed of the ability to make claims on the state. These four components are difficult to analyse; they are not 'things' with fixed, identifiable natures and responsibilities. Rather, they are relationships and, as such, shaped by constant struggle embodied in everyday practices and discourses as much as in formal institutions (Abrams, 1988; Mitchell, 1991). Territories are designated by borders that appear as tangible lines on a map projection, but these borders only work because they are patrolled and defined - even 125 years after the Berlin Congo Conference - by a gentleman's agreement to acknowledge and respect formal claims. Sovereign states are represented by formal bodies such as parliaments, ministries and executive heads that bear some responsibility for public order and welfare but all of these need to be constantly legitimated through practices of consent and coercion. Likewise, the authority of a modern state is outlined in a set of principles and rules that establish political hierarchy and legal practice (such as the writing of contracts) but off the rarefied pages of the Constitution, state and non-state actors alike seize authority through everyday practices of negotiation, governance, oversight and improvement that are as important, if not more so, as the formal rules. Finally, states consist of members - citizens - who participate in state making through a variety of formal channels that mark them as proper subjects: attending school, owning property, voting in elections, paying taxes, pledging allegiance, etc.; and yet the experience of citizenship is highly variable, differentiated by class, status, age, gender, ethnicity and capability. Thus, the formal institutions of the state and governance are important, but they are only one aspect of the multi-faceted relationships represented by each. To fully understand contemporary land deals, we argue that they need to be analysed in particular places and times in order to capture the ways in which the deals shape - and are shaped by - the institutions, practices and discourses of territory, sovereignty, authority and subjects. We question the term 'land grab' and suggest that land deals have no necessary character; they are not necessarily 'win-win' nor do they necessarily entail dispossession and deceit (Cotula and Vermuelen, 2009). Land deals are nothing more (or less) than transformations in the ground on which states are formed.

Our approach to these four components of the state is situated in work being done in the broad fields of political ecology, anthropological analyses of the state and agrarian studies. Political ecology is a theoretically eclectic field defined by its concern with the relationship between people and their environments in the broader context of the state and economy (Blaikie and Brookfield, 1987; Robbins, 2004). Although political ecologists are increasingly re-conceptualizing the field, focusing more on developed economies (McCarthy, 2002; Robbins and Sharp, 2003; Walker and Fortmann, 2003; 
Wainwright, 2005), urban areas (Heynen et al., 2006; Leichenko and Solecki, 2008; Swyngedouw, 2004), and networks, webs and rhizomes (Escobar, 2010; Rocheleau and Roth, 2007), three classical concerns of the literature are relevant to a consideration of land deals and the state. First, the focus on the materiality of production and social reproduction in highly politicized environments helps to illuminate the interconnections between biophysical landscapes and the political economies of development. The characteristics of the physical environment are experienced and represented in ways that shape land deals, whether it be flat plains considered 'ideal' for large-scale, mechanized commodity crop production (Oliveira, 2013: 261-284; see also Deininger et al., 2011; Wolford, 2008), semi-arid savannas and so-called 'marginal lands' re-made into plantations and wilderness parks (Makki and Geisler, 2011), or 'undeveloped' frontier land in dense tropical rain forests (Dwyer, 2013: 309-334; see also Baletti, 2011), unused, undervalued, or state land (Burnod et al., 2013: 357-380) or geographically isolated borderlands (Grajales, 2013: 211-232). Growing interest within political ecology in the construction of nature itself (Braun, 2002; Escobar, 2010; Whatmore, 2002) also provides tools to shed critical light on the relationship between state discourses of 'appropriate' land use and essentializations of gender, class and ethno-racialized identities (Buckley, 2013: 429-450; Fairbairn, 2013: 335-356; Sullivan, 2013: 451-471; see also Bassett, 2002; Sundberg, 2003).

Second, the central role of conflict in political ecology (Moore, 2005; Perrault, 2008) highlights the ways in which different forms of power (state and non-state) shape access to land as well as to labour, income or capital, technology, and rights such that 'struggles over material resources, labour discipline, and surplus appropriation are simultaneously struggles over culturally constructed meanings, definitions, and identities' (Hart, 1997: 45). Attention to conflict is crucial in studying land deals as they have been characterized by violent struggles over ownership and use (see Grajales, 2013: 211232; Levien, 2013: 381-408). These conflicts are shaped by the different meanings associated with land, as a productive asset, a means of livelihood, a home or homeland, a method of achieving stability, etc. (see Graef, 2013: 285-308). Even when land deals occasion no outright resistance or protest, or when dispossession is not accompanied by displacement - what Feldman and Geisler (2011) call 'in situ displacement', and Hall (2011) calls 'adverse incorporation' - there are often small uncoordinated acts of resistance - James Scott's (1985) 'weapons of the weak' - produced in the interstices between ownership and use (see Dwyer, 2013: 309-334).

Finally, many of the papers in this special issue incorporate political ecology's traditional concern with the ethnographic method, focusing on 'land managers' (Blaikie and Brookfield, 1987) and using life histories to analyse the 'thick' questions of subjective interpretation, ideology and intention (Buckley, 2013: 429-450; Fairbairn, 2013: 335356). They illustrate a political ecology of the state by examining not only the role of the state in shaping land deals, but the inner workings of states in shaping new understandings and articulations of territory, sovereignty, authority and subjects.

This focus on the lived experience of governance builds on work loosely defined as the 'anthropology of the state' (Sharma and Gupta, 2006; see Buckley, 2013: 429-450) through which notions of governmentality have become central to an understanding of 
state power and the articulation of subjects (Baka, 2013: 409-428). Our approach builds on work by Ferguson and Gupta (2002; also see Gupta, 1998) who critique the normative conceptualization of society as below an omniscient and omnipresent state (the grassroots as 'on-the-ground' versus the 'top-down' execution of the state). We focus on the construction of territories, sovereignty, authority and subjects precisely to avoid seeing the state where it is not. Understanding the process of governance is an effective way of disrupting the state's own efforts to universalize, naturalize and simplify. In this we inevitably follow Foucault (1991), for whom governmentality - or the 'conduct of conduct' - derived from the problematic of 'how to govern oneself, how to be governed, how to govern others, by whom the people will accept being governed, how to become the best possible governor' (ibid.: 87). As Levien (2013: 381-408) suggests, coordinating land deals is a highly political process that lacks the veiling capacity of the market's invisible hand and so requires 'an extra burden of ideological legitimation' (ibid.) to be accepted by those whose access to land is threatened.

Foucault argued that the modern nation state organizes its subjects (including both people and things) in ways that makes them easier to govern - or 'visible' - by 'rationalizing and standardizing what was a social hieroglyph into a legible and administratively more convenient format' (Scott, 1998: 3). Around the world, the postcolonial art of government is embodied in scientific experts (Buckley, 2013: 429-450) who provide expertise and infrastructure (Grandia, 2013: 233-260), creating a 'technocracy' that disciplined individuals to internalize, accept and perpetuate the conditions of their rule (Mitchell, 2002). As Foucault said, 'when a state is well run, the head of the family will know how to look after his family, his goods and his patrimony, which means that individuals, in turn, behave as they should' (Foucault, 1991: 92). The case studies in this special issue show how state and non-state actors alike work to promote the smooth internalization of hegemonic objectives, although the balance between coercion (Grajales, 2013: 211-232; Levien, 2013: 381-408) and consent (Buckley, 2013: 429-450) varies depending on the legitimacy of the state apparatus and the overlap between official goals and the desires of people on the ground. Analysing this balance requires working at multiple scales to see the ways in which seemingly local actors are influenced by interests and actions at broader scales (see Oliveira, 2013: 261284), while at the same time taking on crucial roles mediating access to land (Baka, 2013: 409-428; Burnod et al., 2013: 429-450; Fairbairn, 2013: 335-356).

Finally, our perspective on the state and land deals is shaped by political economy work in the field of critical agrarian studies (Bernstein, 2010; Borras, 2009; White et al., 2012). The scale and velocity of land acquisitions over the past decade makes 'old' agrarian questions of imperialism, political power and modes of production and reproduction relevant again. The relationship between political organization and capital (the subject of the original agrarian question, c.f. Kautsky, 1899/1989) requires re-examining; state actors from the global South and global North are actively participating in land acquisitions in ways that belie the strict separation between state and capital, and between buyers and sellers (Fairbairn, 2013: 335-356; see also Amanor, 2008; Hall, 2011). New concerns of resource scarcity and commodity production invoke old questions of the relationship between population, ecology and technology, even as states and private investors hedge their bets by purchasing the means to produce individualized 
abundance amidst dearth (McCarthy and Wolford, 2011; McMichael, 2011). Contemporary land deals are thus productively analysed through the lens of what David Harvey (2003) refers to as 'accumulation by dispossession' (see Levien, 2013: 381-408).

Drawing on Marx's discussion of primitive accumulation (Marx, 1990: 873-96; also see Perelman, 2000), Harvey argues that capitalist expansion in the post-Keynesian period (1970s to the present) has been mediated through an equally violent and bloody process of alienation from the means of production, consumption and representation - what Harvey describes as accumulation by predation, force or violence, and what Marx describes as a history dripping in blood, whereby direct producers were separated from the means of production, common property rights were privatized and noncapitalist modes of production were either harnessed or destroyed. In the current phase of capitalist development, this form of accumulation is understood as not original, primitive or previous to capitalism, but instead as intimately tied to the classical political economy notion of capitalist expansion through commodification, juridical individualism and alienation. Contemporary accumulation foregrounds dispossessions that range from: the patenting of genetic codes; the regulation of intellectual property rights; the privatization of everything (including public education); the erosion of state protections such as welfare programmes, public housing and labour rights; polluting and depleting the global environmental commons, and more. In this process, the state is implicated as not only the site of legitimate violence, but as the site of legitimate theft.

Thus, land deals are the speculative continuation of a mode of acquisition begun in the 1950 and 1960 s with the conservative modernization of agriculture - the so-called Green Revolution (Perkins, 1997). Increasing industrialization and technical sophistication of production has pushed the rural poor - smallholders, squatters, sharecroppers, pastoralists - off their land at the same time that environmental degradation pushes them into increasingly confined rural spaces or informal and precarious urban spaces. In many cases, small farmers are able to retain their land only if they enter into production contracts along a top-down value chain that begins with seed companies and ends with increasingly large supermarkets stocked with processed goods (Grandia, 2013: 233-260; Reardon et al., 2005).

In this context, so-called 'land poor' states are now hunting for new ways of feeding their people and fuelling their economies (White and Dasgupta, 2010). Reminiscent of 'petrodollar' investments in the late 1970s, Middle Eastern states flush with returns on highpriced oil are farming out their profits to provide the one thing they don't have: land for agricultural production. The search for land has been heightened by the so-called world food crisis of 2007-08 when food prices reached record levels, rising 80 per cent in eighteen months and pushing the total number of people going hungry to over one billion for the first time in history (von Braun and Meinzen-Dick, 2009; Brown, 2011). Following this peak, food prices fell again, but since 2009 the cost of food has been climbing steadily on global markets, with food prices reaching record highs again in 2011. Over the last five years, the FAO food price index (a measure of the monthly change in international prices of a basket of food commodities) has risen by 92 per cent, and many observers expect food prices to continue to rise, threatening the lives and 
livelihoods of millions of people (Baffes, 2011; Brown, 2011). Thus, the rhetoric behind contemporary investment is dominated by scarcity not surplus (cf. Mehta, 2010; for the scarcity discourse, see Brown, 2011; Collier, 2007).

At the same time, land deals are taking place for reasons related not to food production but rather to extractive development (Grandia, 2013: 233-260), conservation or environmental imperatives shaped by the global community (Graef, 2013: 285-308) and new ventures to profit from old illegal activities (Grajales, 2013: 211-232). There are fertile grounds for investment in land because states, particularly but not exclusively those in the global South, have been hollowed out and pulled back (Peck and Tickell, 1994) after thirty years of neoliberal structural adjustment. Fiscal austerity, high debt loads and reliance on market mechanisms have weakened the capacity of states to structure national development (Dwyer, 2013: 309- 334). Cutbacks in government spending have particularly hurt rural areas as the percentage of domestic and foreign aid directed toward agriculture has dropped precipitously over the past fifteen years (Bezemer and Headey, 2008).

Overall the history of post-war development has been one of increasing urbanization and industrialization, with less focus on - or investment in - agriculture, particularly since the 1980 . This general neglect is increasingly recognized by multilateral agencies and governments (FAO, 2009; IAASTD, 2008) and explains why external investments have been welcomed and sought after by the states included in this special issue (and encouraged by multilateral institutions that imposed austerity conditions in the first place). The rise of neoliberal fiscal austerity and the privatization of many state services and activities have also produced a proliferation of actors on the ground who are involved in land governance, including social movements, non-governmental organizations, international agencies of various kinds, corporations and more. The conflicting motivations of states combined with the rise of multiple actors and a global economy in crisis provide the general context for the governance of the global rush to acquire land. By incorporating attention to this macro-level context, we argue that it will become clearer how territory, sovereignty, authority and subjects have been constituted through multiple iterations of the 'old' agrarian question.

In sum, we argue that the overlapping theoretical and methodological tools of political ecology, anthropological analyses of the state and critical agrarian studies provide a nuanced and necessary perspective on the relationship between land deals and the state. These overlapping fields bring together a set of theoretical frameworks derived primarily from Marx, Gramsci and Foucault with a methodological emphasis on qualitative analyses. The papers in this issue all situate the constitution and contemporary dynamics of new land deals in the political economies and ecologies of particular places; from Guatemala to Senegal and Madagascar they study individual cases in order to highlight the importance of context, scale and everyday interactions in shaping the nature of land transfers. The authors do not assume a priori that there is a necessary character to land deals, rather they frame the deals themselves quite broadly, as embedded in complex multi-scalar webs of relationships shaped by power, property and production. In the section that follows, we outline the contributions the 
papers make to our central analytical themes: territory, sovereignty, authority and subjects.

\section{Territory}

'If I lose my land, I lose my country' (Mirta, a Paraguayan peasant, quoted in Fernandes, 2009: 197).

Land is the symbolic and material ground on which states produce and reproduce themselves; land is the stage across which the 'imagined community' (Anderson, 1983) of the nation state unfolds and grounds itself. As such, and as we have already suggested, territory has a concrete, physical manifestation on the land, as well as abstract and symbolic meanings as a particular sort of national space (Fernandes, 2008). The papers in this section all focus on this duality of territory and highlight the ideological and political narratives that perpetuate the desire for large-scale land investment in parts of the national territory that are rendered distant (Grajales) or lawless (Grandia) or ripe for investment (Oliveira). These narratives may begin at the national level but succeed only if they are echoed by elite and non-elite actors from investors to politicians to paramilitary guards to ordinary people on the street. Territorial claims and visions must be sanctioned by a collective and either legitimated by the consent of those within or forced upon them. As such, territories include those carved out by state rule as well as those performed by indigenous or subaltern communities that may not have formal or official access to the land. For these communities, territory is 'made' through everyday use, memorialization of past generations of use and the collectivization of histories and practices on the land. The papers in this special issue that speak to territory explore the problematic and complex relationships between territory and rule, both of which play a role shaping the nature and extent of land deals in any given region.

The contribution by Jacobo Grajales illustrates the illicit connections between the state and the production of illegal drugs in the Lower Atrato Valley in northwestern Colombia. This is a 'territory in dispute', according to Grajales, from which tens of thousands of Colombian peasants were expelled because of violent counter-insurgency attacks by the Colombian military and paramilitaries. This forced displacement has created an 'invisible' landscape in which extra-legal actors have been able to transform their returns from counter-insurgency and the drug trade into legal profits from statesupported large-scale oil palm plantations. The connections between paramilitary violence in clearing out frontier regions of the state, first for drug-running activities and then biofuel plantations, suggests a clear link between abuses of power, complicit states, ethnic cleansing, international priorities for 'clean fuel' and trade-driven investment. In Colombia, decades of civil violence 'opened a window of opportunity' for the entrance of state and paramilitary actors who profit from the insecurities of agricultural production and the international agreements intended to stem the drug trade on one hand while encouraging the laundering of money from criminal activities into newly legitimate fields of biofuel production. For Grajales, land grabbing is a clever institutional mechanism that allows illegal territory to become legal in the Colombian context. 
The paper by Liza Grandia highlights the pivotal role of an 'ambitious new wave of big infrastructure programmes' across the global South - multi-state infrastructure that links areas of extraction such as mineral deposits, biofuel production, timber reserves, food plantations, carbon-based energy supplies and more to coastal ports and, thus, to international markets. Grandia specifically investigates the role that such infrastructure initiatives have in re-writing indigenous territories in Guatemala. She presents research from fieldwork in the department of Peten, what she calls the 'last frontier' in Guatemela where Mayan or 'Yeomayan' farmers had managed to achieve a level of selfsufficiency and success but are now being threatened by commercial interests who arrive in the region on the backs of state investment in new infrastructure. Grandia outlines the ways in which the Guatemalan state in conjunction with three different kinds of actors - environmentalists, cattle ranchers and narcotics traffickers - all attempt to control this frontier territory through planning, mapping and road building. She suggests that there are other ways of organizing the relationship between production and property and shows how historical power struggles complicate the search for peaceable alternatives.

The contribution by Gustavo Oliveira focuses on Brazil, one of the primary sources and sites of new land deals in South America. Oliveira examines a land regularization and development programme intended to bring order to the zone of transition between the Amazon forest region to the North and the grassland Cerrado region to the South. Oliveira argues that these two areas comprise very different territories in the Brazilian imaginary and these differences are reflected in distinct governance strategies that close the Amazon to land deals while opening the Cerrado. Building on histories of state developmentalism and environmental action, the former territory has come to be seen as a region to be regulated such that contemporary attempts to provide clear land title in the Amazon have gone hand in hand with an attempt to curtail deforestation and largescale land transfers. In the Cerrado, however, the territory is imagined as ideal for largescale agro-industrial development and the state has facilitated large-scale investment there since the 1980s. It is in this latter region that land deals are concentrated. Oliveira argues that although the territorial policies are differentiated in these two regions, state making through property regularization in their transition zone links two seemingly distinct and contradictory processes in such a way that protecting the bulk of the delicate (and internationally renowned) Amazonian region allows the state to sacrifice the Cerrado to agricultural and extractivist land deals, thus consolidating the agribusiness mode of production in the transition zone.

These discussions of land deals treat territory in different ways, but all highlight the contingent state-making practices involved in claiming and negotiating access not just to physical pieces of land, but also to the ideological aspects of defining territory.

\section{Sovereignty}

The literature on sovereignty has tended to focus on sovereign rulers and on political relationships between states within the global community where borders denote the capacity to govern. But sovereignty also refers to the ability of people in a given community to control their own fate whether through localized resources or the capacity to access state resources that buffer persons from risk. This definition is increasingly captured by 
social movement campaigns and demands for 'food and land sovereignty' or the right of local communities and states to control their food production and consumption networks. The vision by which this could happen is through the 'articulated autonomy' of communities producing a diversity of goods, activities, services, uses and identities, and building alliances through social networks. In this respect, social movements under the umbrella of Via Campesina argue that sovereignty does not mean ignoring the state or the market. Rather, activists echo Karl Polanyi (1944/2001) in suggesting that trade must be subordinated to the needs of the community, not the other way around.

In examining sovereignty, the papers in this special issue analyse the relationship between land deals, property and the autonomy or privilege of modern nation states. Although it could be argued that nation states have never truly been sovereign always subject to the whims and movements of financial and other forms of capital the narrative of state sovereignty is necessary to defend the nation state's authority as the law and strong arm of the land. All of the papers in this section question the coherence of sovereignty and suggest that extractive land deals may be fundamentally redefining the nature and meaning of sovereign power. When control is ceded to 'outsiders' in multi-thousand hectare increments and ninety-year contracts, state actors struggle to maintain and adapt positions of sovereignty; new actors and interests increasingly shape decisions over which powers are retained by the state (penal, juridical, legal) and which are to be forfeited (political, financial). In this new context of global governance and 'fragmented sovereignty', the papers in this section analyse new discourses of environmental sovereignty (Graef) and outline the internally differentiated impacts that land deals have on localized sovereignties (Fairbairn) and central powers (Dwyer).

Dana Graef provides a historical analysis of past land concessions in Costa Rica, illustrating the important role played by collective memories, and how those memories continue to change and be vested with new meaning as the context changes. Graef details two different land concessions - one for a bauxite mining operation that would have been headed by a US company and one for a large-scale dam that would have been built and managed by a state entity - neither of which was ever implemented but both of which forced political leaders, local inhabitants and corporate officers to present their own understandings of Costa Rican sovereignty and the nature of the nation state. She shows how protests against the first project were framed as anti-imperialism while support for the second was framed as promoting national environmental sovereignty, even as it received criticism from environmentalists for reducing biodiversity and from indigenous peoples and peasants for trammelling alternative territories.

Michael Dwyer argues for a grounded, empirical understanding of the development landscape on which contemporary land deals are taking place in Laos. He illustrates the strength of normative discourses (and fears) around sovereignty and loss of sovereignty when a mis-cited picture presented in the media was widely assumed to show Chinese rubber plantations on Laotian soil. He provides rich detail to argue that the Laotian central state has indeed ceded vital aspects of state sovereignty to the Chinese - both literally in large land concessions for rubber and palm oil plantations, and indirectly, by 'failing to either set policy or provide economic support to would-be smallholders'. 
Even so, Dwyer argues that negotiating large-scale transnational land deals has helped to support and strengthen the sovereignty of central state elites.

In her contribution, Madeleine Fairbairn analyses the legal, financial and social underpinnings of access to land in Mozambique. She argues that local-level elites exercise 'access control' (after Peluso and Ribot, 2003) by mediating access to land. The recent rise of interest in Mozambique as an ideal site for agricultural investment is thus mediated by elites who derive power from five key sources: traditional authority, bureaucratic influence, historical access, locally-based business knowledge and networks, and the power to set development agendas. Because this 'fragmented sovereignty' is so localized, the end results of land deals are very different in different regions of the country. Ultimately, Fairbairn argues that although community land rights and traditional forms of access to land have been given lip service in the country, local-level elites fight each other for the right to overturn these forms of access when offered the opportunity to profit from expropriation.

By focusing on different modes, sites and means of sovereignty, these papers all tie in concepts of rights and rule to the study of land deals. While there is no necessary, predetermined outcome in terms of the effects of land deals for national sovereignty, the emphasis on North-South financial and political flows does suggest that special attention needs to be paid to the ways in which local elites counter and negotiate threats to their control over resources.

\section{Authority}

Moving from the abstract concept of the all-seeing state, in which ultimate authority is vested in a top-down set of institutions, the papers in this special issue focus on authority - or on the capacity to assume decision-making power in a given context. Authority differs from power as those who have power may choose not to display or impose their authority in particular situations; but authority is similar to power in that it is not an object that inheres in positions or people. Instead, authority, like power, is a relationship between two or more parties in which some are able to claim and deploy the right to make meaningful decisions. At the present moment, there are an ever-increasing number of actors on the ground who authorize land deals and land-related activities in any given place. The concomitant though seemingly opposed movements towards increasing democracy and decentralization of authority and the weakening of the central state through neoliberal directives and pressures have given rise to a multitude of social movement actors, local political elites, religious leaders, non-governmental organizers, institutional bureaucrats and more, all of whom claim authority through varying legal, social, cultural and economic practices. All the contributions to this special issue deal with authority on some level, but two in this section invoke authority in particularly interesting and specific ways.

Perrine Burnod et al. argue that authority takes many different forms and that the multiple and overlapping arenas in which political and economic elites operate in Madagascar complicates attempts to organize or order land claims. Directly speaking to the paradox described above, where deepening democracy overlaps and conflicts with neoliberal state restructuring, in Madagascar a radical new land reform policy from 
2005 recognized local and community land use for the first time in the country's history even as the government engaged in an aggressive campaign to attract foreign investment in agricultural production. This paradoxical strengthening and weakening of community access to land came to light in the protests over attempts by a South Korean firm (Daewoo Logistics) to purchase one third of the country's arable land; unrest succeeded in toppling the government and seemed to strengthen community claims even further. Burnod et al. argue, however, that competition over 'access control' occurs both in state and non-state arenas; state and local elites both strive to impose new constraints on investors as a way to assert their authority over land management and to consolidate formal control over territory. In the process, the 2005 laws which were intended to promote the decentralization of land management and legal recognition of smallholders' land rights are not enforced and land management becomes recentralized. Multiple and overlapping claims to authority generate a proliferation of new administrative obstacles to land deals which, on the one hand, privilege investors with considerable capital, and on the other hand exacerbate intra-community conflicts and displace small farmers and land users.

Michael Levien historicizes the discussion of land deals in contemporary India, and argues that dispossession has been an important 'featuread of colonial, post-colonial and neoliberal political economy' but with distinct temporal and spatial features. He periodizes what he calls 'regimes of dispossession' in India, which he defines as 'socially and historically specific constellation[s] of political, economic and ideological forces that underpin a relatively consistent pattern of dispossession'. Levien argues that in the early post-war period, the Indian state was directly involved in creating industrial zones for national development; these industrial spaces required expropriation but acquired legitimacy in the eyes of the nation (if not in the eyes of the dispossessed) because the goal was seen as the good of all - progress and the future of the modern nation. More recently, the state has stepped out of the direct developmental role, taking on the position of mediator, expropriating people from the land for the purposes of outside investment. Here, the state acts as a broker, furnishing the dispossessed land to the market. Levien argues that this brute transfer of land from one group to another is not as easily accepted as the developmental initiatives, and so the authority of the state and of the transfers is thrown into question. With a detailed case study from the state of Rajasthan, Levien outlines the ideological work the state does to legitimize its role as land broker and the resistance that follows in its wake.

\section{Subjects}

Perhaps the most important contribution of the papers in this special issue is the detailed focus on the process by which actually-existing land deals are conducted and the implications for the people who live and work on the land. As is already clear, land is much more than a physical resource or the arena for state activity; land is life, stability, livelihood and social reproduction. Identities and subject positions are constituted through relationships on and with the land; and in this section, the authors argue that identifying certain groups as marginal or unproductive or lazy allows land deals to be seen as common sense and eminently logical. From experiences of dispossession and marginalization to redefinitions of productivity and belonging, a focus on subject formation embeds land deals in bodies, households, communities and government offices 
and illuminates the possibilities and challenges of land transfers for local and national well-being. In the section on subjects, the authors analyse specific cases to focus on the ways in which land deals are producing new kinds of subjects: the dispossessed and marginalized small farmers who sell a piece of their land for biofuels only to find themselves dispossessed by urban developers (Baka); the international agricultural extension agents who perform a complicated dance trying to teach new African farmers how to farm like Chinese farmers (Buckley); and the racialized indigenous peoples in Brazil who struggle for access to land as the fulfilment of heritage and self (Sullivan). Jennifer Baka provides detailed evidence of land deals in India in which developers amassed large quantities of land, taking advantage of legal rules governing land defined as marginal or wasteland that could be converted to biofuels production. Farmers have sold pieces of their land (sometimes knowingly, sometimes not) thinking that it would be used for jatropha production, but the jatropha trees had barely been planted when the land was converted for use in industrial and urban development. As real estate transactions swallowed up the former farmland, farmers found their hold on the remainder of their land was weak. Thus, land deals have changed their relationship to the land in ways that have enormous implications for livelihood and the ability of local communities to provision themselves.

In her paper, Lila Buckley presents a case study of Chinese extension workers in an agricultural demonstration centre in Senegal. This contribution provides an ethnographic look into the much-discussed Chinese presence in African agriculture and development. Buckley argues that agricultural and aid work should be thought of as a performance between different subjects who bring very different ideas, norms and goals to their work. She describes the Chinese aid workers as separating 'work' (which one does in the office and in the field, training farmers to do agriculture better, to adopt Chinese methods and agro-ecological principles) and social time, whereas their Senegalese counterparts consider work and social time to be one and the same, such that tensions arise. The Chinese believe the Senegalese are lazy and do not like to work, while the Senegalese believe the Chinese are rude and interested only in extracting profit from the efforts of others, taking everything that is produced through the centre to be sold or returned to China. Buckley shows how this performance between the Chinese and Senegalese changes when it is taken 'off-stage' and onto fields where the former are able to interact directly with farmers; it is there that land management techniques are transferred more successfully. This paper suggests that Chinese interest in land on the African continent will not just manifest in large-scale land deals but will also be performed and negotiated in the realm of cultural subjectivities.

LaShandra Sullivan examines large-scale land deals in the Brazilian mid-west, arguing that the construction of ethno-racial categories shapes the manner in which such deals develop. Surely it is true that racializations of various sorts run through attempts to categorize land as marginal and underproductive and land deals as legitimate or useful. Sullivan describes the ways in which 'land serves as a point of struggle both in one's material reproduction and in competing maps in narratives of belonging, subjectivity and citizenship'. In the Brazilian state of Mato Grosso do Sul, indigenous peoples find their land appropriated by well-meaning officials who hope to rationalize production while non-indigenous peoples fear that their land could in turn be 
taken through state efforts to repatriate territorial homelands to increasingly wellorganized and vocal indigenous social movements. The fear of losing land shapes new narratives of the ideal land use and users; as such, Sullivan argues that 'a subject gains recognition through "being" an identity as facilitated through territorial claims'.

\section{Conclusion}

As a whole, the papers in this special issue provide new empirical material for the growing body of literature and research on land deals as well as building a theoretical toolkit and approach for thinking about the state and the role of political power in their negotiation, construction and implementation. The various contributions analyse contemporary land deals from a range of vantage points, including examination of how discourses condition, and are conditioned through, land deals; how legal frameworks, bureaucratic structures and customary laws regulate land access and management; how the internal negotiation and reworking of internal power relations (such as those between the state and paramilitary organizations) condition land acquisition and dispossession; and how meanings of land and territory, and their associated categories of identity and belonging, are produced, articulated and mobilized in relation to land deals.

In this Introduction, we argue that portrayals of the state as weak or corrupt and of the need for good governance as a solution to the excesses of expropriation are overly facile and need to be replaced with nuanced analyses of the ways in which power flows through the various disaggregated levels and functions of the state. We suggest that unbundling the state to focus on four components - territory, sovereignty, authority and subjects - helps to sharpen both the empirical and theoretical focus on land deals. In so doing, the papers in this issue problematize the concept of 'land grabbing' itself by complicating the notion that global land deals are a 'top-down phenomenon driven by global markets or foreign states' (Fairbairn, 2013: 335-356).

While investors indeed play a critical role in land deal politics and outcomes, the research in this issue warns against a deterministic (and simplistic) understanding of power and its effects in global land acquisition. Instead, these papers suggest a relational understanding of power in which host state representatives, local and regional elites, paramilitary organizations and smallholders, indigenous and marginal communities are also critical actors in land deals. Certainly there is unevenness in power relations, but the particular forms, practices and effects of power must be understood in geographically and historically specific terms if we are to adequately address the multiple and diverse practices of land grabs, and the heterogeneous modes and forms of dispossession they generate. 


\section{References}

Abrams, P. (1988) 'Notes on the Difficulty of Studying the State (1977)', Journal of Historical Sociology 1(1): 58-89.

Amanor, K.S. (2008) 'Sustainable Development, Corporate Accumulation and Community Expropriation: Land and Natural Resources in West Africa', in K.S. Amanor and S. Moyo (eds) Land and Sustainable Development in Africa, pp. 127-58. London and New York: Zed Books.

Anderson, B. (1983) Imagined Communities: Reflections on the Origin and Spread of Nationalism. London: Verso.

Arezki, R., K. Deininger and H. Selod (2011) 'What Drives the Global "Land Rush"?'. World Bank Policy Research Working Paper No. 5864. Washington, DC: World Bank.

Ariyo, J. and M. Mortimore (2011) 'Land Deals for Commercial Agriculture in Shonga, Nigeria: The Policy Challenge'. Policy brief. Nairobi/Brighton: Future Agricultures Consortium.

Baffes, J. (2011) 'The Long-term Implications of the 2007-08 Commodity-Price Boom', Development in Practice 21(4-5): 517-25.

Baletti, B. (2011) 'Saving the Amazon? Land Grabs and "Sustainable Soy" as the New Logic of Conservation'. Paper presented at the International Conference on Global Land Grabbing, Institute for Development Studies, University of Sussex (6-9 April).

Bassett, T. (2002) 'Women's Cotton and the Spaces of Gender Politics in Northern Cote d'Ivoire', Gender, Place, and Culture 9(4): 351-70.

Bernstein, H. (2010) Class Dynamics of Agrarian Change. Toronto: Fernwood Publishing. Bezemer, D. and D. Headey (2008) 'Agriculture, Development and Urban Bias', World Development 36(8): 1342-64.

Blaikie, P. and H. Brookfield (1987) Land Degradation and Society. London: Methuen. Bomuhangi, A., C. Doss and R. Meinzen-Dick (2011) 'Who Owns the Land? Perspectives from Rural Ugandans and Implications for Land Acquisitions'. IFPRI Discussion Paper No. 01136. Washington, DC: International Food Policy Research Institute (IFPRI).

Borras Jr., S.M. (ed.) (2009) Critical Perspectives in Rural Development Studies. London: Routledge Press.

Borras Jr., S.M., R. Hall, I. Scoones, B. White and W. Wolford (2011) 'Towards a Better Understanding of Global Land Grabbing: An Editorial Introduction', Journal of Peasant Studies 38(2): 209-16.

Braun, B. (2002) The Intemperate Rainforest: Nature, Culture, and Power on Canada's West Coast. Minneapolis, MN: University of Minnesota Press.

von Braun, J. and R. Meinzen-Dick (2009) “Land Grabbing” by Foreign Investors in Developing Countries: Risks and Opportunities'. Policy Brief. Washington, DC: International Food Policy Research Institute (IFPRI).

Brown, L. (2011) 'The Great Food Crisis of 2011', Foreign Policy. http://www.foreignpolicy. com/articles/2011/o1/10/the_great_food_crisis_of_2011?page=0,1\&sms_ss=emai $1 \&$ at_xt=4d2bdf949cb64bf1,o

Collier, P. (2007) The Bottom Billion: Why the Poorest Countries are Failing and What can Be Done About It. Oxford: Oxford University Press. 
Cotula, L. and S. Vermeulen (2009) 'Deal or No Deal: The Outlook for Agricultural Land Investment in Africa', International Affairs 85(6): 1233-47.

Cotula, L., S. Vermeulen, R. Leonard and J. Keeley (2009) Land Grab or Development Opportunity? Agricultural Investment and International Land Deals in Africa. London/Rome: International Institute for Environment and Development, Food and Agricultural Organization of the United Nations, and International Fund for Agricultural Development.

Daniel, S. and A. Mittal (2010) (Mis)Investment in Agriculture. The Role of the International Finance Corporation in Global Land Grabs. Oakland, CA: The Oakland Institute.

Deininger, K., D. Byerlee, J. Lindsay, A. Norton, H. Selod and M. Stickler (2011) Rising Global Interest in Farmland: Can it Yield Sustainable and Equitable Benefits? Washington, DC: World Bank.

The Economist (2011) 'The Surge in Land Deals: When Others are Grabbing their Land', 5 May. http://www.economist.com/node/18648855?story_id=18648855 (accessed 6 May 2011).

Escobar, A. (2010) Territories of Difference: Place, Movements, Life, Redes. Durham, NC: Duke University Press.

Fairhead, J., M. Leach and I. Scoones (eds) (2012) 'Green Grabs: A New Appropriation of Nature?', The Journal of Peasant Studies 39(2): 237-61 (Special Issue).

Feldman, S. and C. Geisler (2011) 'Land Grabbing in Bangladesh: In-Situ Displacement of Peasant Holdings'. Paper presented at the International Conference on Global Land Grabbing, Institute of Development Studies, University of Sussex (6-9 April).

Ferguson, J. and A. Gupta (2002) 'Spatializing States: Toward an Ethnography of Neoliberal Governmentality', American Ethnologist 29(4): 981-1002.

Fernandes, B.M. (2008) 'Conflitualidade e Desenvolvimento Territorial' ['Confllict and Territorial Development'], in A.M. Buainain and B.M. Fernandes (eds) Luta Pela Terra, Reforma Agrá ria e Gestão de Conflitos no Brasil [The Struggle for Land, Agrarian Reform and Conflict Management in Brazil], pp. 173-231. Campinas, SP, Brasil: Editora Unicamp.

Fernandes, B.M. (2009) 'Sobre a Tipologia de Territó rios' ['On the Typology of Territories'], in M.A. Saquet and E.S. Spó sito Territó rios e Territorialidade: teorias, processos e conflitos [Territories and Territoriality: Theories, Processes and Conflicts] pp. 197-216. Sã o Paulo: Expressã o Popular.

Food and Agricultural Organization (FAO) (2009) 'From Land Grab to Win-Win: Seizing the Opportunities of International Investments in Agriculture'. Policy Brief No. 4. Rome: FAO.

Foucault, M. (1991) 'Governmentality', in G. Burchell, C. Gordon and P. Miller (eds) The Foucault Effect: Studies in Governmentality, pp. 84-104. Chicago, IL: University of Chicago Press.

Gupta, A. (1998) Postcolonial Developments: Agriculture in the Making of Modern India. Durham, NC: Duke University Press.

Hall, R. (2011) 'Land Grabbing in Southern Africa: The Many Faces of the Investor Rush', Review of African Political Economy 128: 193-214.

Hart, G. (1997) 'Multiple Trajectories of Rural Industrialization: An Agrarian Critique of Industrial Restructuring and the New Institutionalism', in D. Goodman and M.J. 
Watts (eds) Globalising Food: Agrarian Questions and Global Restructuring, pp. 41-57. New York: Routledge.

Harvey, D. (2003) The New Imperialism: Accumulation by Dispossession. Oxford: Oxford University Press.

Heynen, N., M. Kaika and E. Swyngedouw (eds) (2006) In the Nature of Cities: Urban Political Politics of Urban Metabolism. London: Routledge.

HLPE (2011) 'Land Tenure and International Investments in Agriculture'. A Report by the High Level Panel of Experts on Food Security and Nutrition of the Committee on World Food Security. Rome: HLPE.

IAASTD (2008) 'Agriculture at a Crossroads: International Assessment of Agriculture, Science, Technology and Development'. Washington, DC: Island Press.

Kautsky, K. (1899/1989) The Agrarian Question. London: Zwan.

Landesa (2011) 'The Land Rush: A Fact Sheet on Commercial Land Acquisitions in Developing Countries'. http://www.landesa.org/our-researchpublications/issue/briefs/

Leichenko, R. and W. Solecki (2008) 'Consumption, Inequity, and Environmental Justice: The Making of New Metropolitan Landscapes in Developing Countries', Society and Natural Resources 21(7): 611-24.

Li, T.M. (2011) 'Centering Labor in the Land Grab Debate', Journal of Peasant Studies 38(2): 281-98.

Makki, F. and C. Geisler (2011) 'Development by Dispossession: Land Grabbing as New Enclosures in Contemporary Ethiopia'. Paper presented at the International Conference on Global Land Grabbing, Land Deal Politics Initiative, Institute for Development Studies, University of Sussex (6-8 April).

Marx, K. (1990) Capital: A Critique of Political Economy. London: Penguin Books. McCarthy, J.P. (2002) 'First World Political Ecology: Lessons from the Wise Use Movement', Environment and Planning A 34(7): 1281-302.

McCarthy, J. and W. Wolford (2011) 'Land, Energy, Water: From Scarcity to Security'. Final Report for Oxfam America (unpublished).

McMichael, P. (2011) 'Food System Sustainability: Questions of Environmental Governance in the New World (Dis)order', Global Environmental Change 21(3): 804-12.

Mehta, L. (ed.) (2010) The Limits to Scarcity: Contesting the Politics of Allocation. London: Earthscan.

Mitchell, T. (1991) 'The Limits of the State: Beyond Statist Approaches and their Critics', American Political Science Review 85(1): 77-96.

Mitchell, T. (2002) Rule of Experts: Egypt, Techno-politics, Modernity. Berkeley, CA: University of California Press.

Moore, D. (2005) Suffering for Territory: Race, Place, and Power in Zimbabwe. Durham, NC: Duke University Press.

Morris, M.L., H.P. Binswanger-Mkhize and D. Byerlee (2009) Awakening Africa's Sleeping Giant: Prospects for Commercial Agriculture in the Guinea Savannah Zone and Beyond. Washington, DC: World Bank.

Oxfam (2010) 'Addressing Land Grabbing in Africa: Why Governments Should Stand Up for Marginalised Communities'. Oxford: Oxfam (13 September).

Oxfam (2011) 'Land and Power: The Growing Scandal Surrounding the New Wave of Investments in Land'. Oxfam Briefing Paper 151 (22 September). 
http://policy-practice.oxfam.org.uk/publications/land-and-power-the-growingscandal-surrounding-the-new-wave-of-investments-in-l-142858

Peck, J. and A. Tickell (1994) 'Jungle Law Breaks Out: Neoliberalism and Global-Local Disorder', Area 26(4): 317-26.

Pelsuo, N. and C. Lund (2011) 'New Frontiers of Land Control: Introduction', Journal of Peasant Studies 38(4): 667-81.

Perelman, M. (2000) The Invention of Capitalism: Classical Political Economy and the Secret History of Primitive Accumulation. Durham, NC: Duke University Press. Perkins, J. (1997) Geopolitics and the Green Revolution. Oxford: Oxford University Press.

Perrault, T. (2008) 'Custom and Contradiction: Rural Water Governance and the Politics of Usos y Costumbres in Bolivia's Irrigators' Movement', Annals of the Association of American Geographers 98(4): 834-54.

Polanyi, K. (1944/2001) The Great Transformation ( $2^{\text {nd }}$ edn). London: Beacon Press.

Reardon, T., J.A. Berdegue and C.P. Timmer (2005) 'Supermarketization of the Emerging Markets of the Pacific Rim: Development and Trade Implications', Journal of Food Distribution Research 36(1): 3-12.

Ribot, J. and N. Peluso (2003) 'A Theory of Access', Rural Sociology 68(2): 153-81. Robbins, P. (2004) Political Ecology: A Critical Introduction. Oxford: Blackwell Press.

Robbins, P. and J. Sharp (2003) 'Producing and Consuming Chemicals: The Moral Economy of the American Lawn', Land Use Policy 20: 181-94.

Robertson, B. and P. Pinstrup-Anderson (2010) 'Global Land Acquisition: NeoColonialism or Development Opportunity?', Food Security 2(3): 271-83.

Rocheleau, D. and R. Roth (2007) 'Rooted Networks, Relational Webs and Powers of Connection: Rethinking Human and Political Ecologies', Geoforum 38(2): 433-37.

de Schutter, O. (2011) 'How Not to Think of Land-Grabbing: Three Critiques of Largescale Investments in Farmland', Journal of Peasant Studies 38(2): 249-79.

Scott, J. (1985) Weapons of the Weak: Everyday Forms of Peasant Resistance. New Haven, CT: Yale University Press.

Scott, J. (1998) Seeing Like a State: How Certain Schemes to Improve the Human Condition Have Failed. New Haven, CT: Yale University Press.

Sharma, A. and A. Gupta (2006) The Anthropology of the State: A Reader. London: Blackwell Publishing.

Sundberg, J. (2003) 'Conservation and Democratization: Constituting Citizenship in the Maya Biosphere Reserve, Guatemala', Political Geography 22: 715-40.

Swyngedouw, E. (2004) Social Power and the Urbanisation of Water: Flows of Power. Oxford: Oxford University Press.

Via Campesina (2011) 'Conference Declaration: Stop Land Grabbing Now!'. http://viacampesina.org/en/index.php?option=com_content\&view=article\&id=115 4: stop-land-grabbing-now\&catid=23:agrarian-reform\&Itemid $=36$

Wainwright, J. (2005) 'The Geographies of Political Ecology: After Edward Said', Environment and Planning A 37: 1033-43.

Walker, P.A. and L.P. Fortmann (2003) 'Whose Landscape? A Political Ecology of the "Exurban" Sierra', Cultural Geographies 10(4): 469-91.

Whatmore, S. (2002) Hybrid Geographies: Natures, Cultures, Spaces. London: Sage.

White, B. and A. Dasgupta (2010) 'Agrofuels Capitalism: A View from Political Economy', Journal of Peasant Studies 37(4): 593-607. 
White, B., S.M. Borras Jr., R. Hall, I. Scoones and W. Wolford (2012) 'The New Enclosures: Critical Perspectives on Corporate Land Deals', Journal of Peasant Studies 39(3-4): 619-47 (Special Issue).

Wolford, W. (2008) 'Environmental Justice and the Construction of Scale in Brazilian Agriculture', Society \& Natural Resources 21(7): 641-55.

Zoomers, A. (2010) 'Globalisation and the Foreignisation of Space: Seven Processes Driving the Current Global Land Grab', Journal of Peasant Studies 37(2): 429-47. 